\title{
UPAYA PENINGKATAN HASIL BELAJAR LOMPAT JAUH GAYA JONGKOK MELALUI PENDEKATAN BERMAIN
}

\author{
Winarno $^{(1)}$, Agus Margono ${ }^{(2)}$ Deddy Whinata Kardiyanto ${ }^{(2)}$ \\ (1) (2) (3) Universitas Sebelas Maret Surakarta
}

\begin{abstract}
The purpose of this research is to improve learning outcomes in the long jump squat style class VII B SMP Negeri 8 Surakarta in academic year $2017 / 2018$.

This study is a classroom action research conducted in two cycles, and each cycle consists of 2 meetings. Research subjects of students of class VII B, amounting to 32 students. The data source comes from students, teachers, and researchers. Data collection techniques use tests and observations. Data validity is by using data triangulation technique. Data analysis used qualitative descriptive analysis technique using percentage technique.

The results of data analysis showed an increase learning outcomes long jump squat style as follows. The percentage of completeness in the pre-cycles is $31.25 \%$ or 10 students, unfinished $68.75 \%$ or 22 students. The percentage of completeness in the first cycle is $46.88 \%$ or 15 students, untargets $53.12 \%$ or 17 students. While on the percentage of completeness in the second cycle is $81.25 \%$ or 26 students, untargets $18.75 \%$ or 6 students. Learning outcomes long jump squat style has reached a target attainment of $80 \%$.

Based on the analysis above it can be concluded; that the application of the method of approach play can improve learning outcomes in the long jump squat style class VII B SMP Negeri 8 Surakarta in academic year 2017/2018.
\end{abstract}

Keywords: Learning outcomes, Style Long Jump Squat, Playing Approach Implementation Method. 
PENDAHULUAN

Pendidikan

Jasmani

(Penjas) bertujuan untuk mengembangkan kemampuan organik, neuromoskuler, intelektual dan emosional secara menyeluruh. Sebagai bagian integral dari pendidikan pada umumnya. Pendidikan Jasmani memberikan kontribusi besar bagi pencapaian tujuan-tujuan pendidikan pada umumnya. Penjas memegang peranan penting dalam mengembangkan nilai-nilai humanitas yang diorientasikan pada peningkatan kualitas manusia seutuhnya. Penjas di tingkatkan di sekolah dengan tujuan untuk membantu siswa dalam meningkatkan kesegaran jasmani dan kesehatan melalui pengenalan dan penanaman sikap positif, serta kemampuan gerak dasar dan berbagai pendekatan jasmani bagi siswa. Oleh karena itu Penjas dan kesehatan merupakan mata pelajaran wajib yang dilaksanakan sesuai dengan kurikulum yang berlaku. Ini terbukti bahwa Pendidikan Jasmani diberikan pada tiap-tiap sekolah mulai dari Taman KanakKanak, Sekolah Dasar, Sekolah Menengah, sampai dengan Perguruan Tinggi.

Salah satu masalah utama dalam pendidikan jasmani di Indonesia hingga dewasa ini adalah belum efektifnya pengajaran Penjas di sekolahsekolah. Pengajaran Pendidikan Jasmani yang efektif dalam kenyataan lebih dari sekedar mengembangkan keterampilan olahraga. Pengajaran tersebut pada hakikatnya merupakan proses sistematis yang di arahkan pada pengembangan pribadi anak seutuhnya.

Kegiatan belajar mengajar dalam pelajaran Pendidikan Jasmani berbeda pelaksanaannya dari pembelajaran mata pelajaran lain. Pendidikan Jasmani adalah pendidikan melalui aktivitas jasmani. Dengan berpartisipasi dalam aktivitas fisik, siswa dapat 
menguasai keterampilan dan pengetahuan, mengembangkan apresiasi estetis, mengembangngkan keterampilan generik serta nilai dan sikap yang positif, dan memperbaiki kondisi fisik tubuh untuk mencapai tujuan Pendidikan Jasmani. Pada dasarnya program Pendidikan Jasmani memiliki kepentingan yang relatif sama dengan program pendidikan lainnya dalam hal ranah pembelajaran, yaitu samasama mengembangkan tiga ranah utama yaitu psikomotor, afektif dan kognitif. Namun, ada kekhasan dari program Pendidikan Jasmani yang tidak dimiliki program pendidikan lainnya, yaitu dalam hal mengembangkan wilayah psikomotor, yang biasanya dicapai dengan tujuan mengembangkan kebugaran jasmani anak dan pencapaian keterampilan geraknya.

Kondisi belum efektifnya kegiatan pembelajaran tersebut disebabkan oleh beberapa faktor diantaranya ialah kurangnya sarana dan prasarana olahraga, kurangnya variasi pengembangan metode pembelajaran dalam memberikan materi pelajaran sehingga membuat siswa cepat bosan saat mengikuti pelajaran olahraga karena materi yang terlalu monoton dan tidak menjadikan pelajaran olahraga menjadi bagian pelajaran yang digemari dan dinanti-nantikan.

Fenomena itulah yang terjadi di SMP Negeri 8 Surakarta. Hasil observasi dan wawancara peneliti dengan salah satu guru Penjasorkes di SMP Negeri 8 Surakarta mengatakan pada saat pembelajaran Penjasorkes materi lompat jauh gaya jongkok, anak cenderung malas mengikuti pelajaran, berbeda saat materi pelajaran sepak bola, renang atau bola basket anak cenderung bersemangat. Pada saat pembelajaran lompat jauh gaya jongkok masih banyak siswa yang duduk dan berteduh saat pembelajaran, selain itu setelah peneliti bertanya pada salah satu murid kelas VII B mengatakan pembelajarannya bersifat 
monoton kurang menarik sehingga membuat siswa cepat jenuh sehingga motivasi mereka untuk mengikuti pembelajaran berkurang. Menurut pengalaman saya saat observasi di SMP Negeri 8 Surakarta, pada kelas VII B, untuk materi lompat jauh gaya jongkok dengan batas tuntas untuk putra 3,5 meter dan putri 2,5 meter, tapi pada kenyataan di lapangan tidak sampai $50 \%$ yang mencapai batas tuntas, dari 32 siswa hanya 10 yang bias dikatakan lulus atau mencapai batas tuntas. Menurut guru penjasorkes yang bersangkutan dan beliau menjelaskan KKM (Kriteria Ketuntasan Minimal) untuk mata pelajaran penjasorkes kelas VII B di SMP Negeri 8 Surakarta adalah 75, sehingga semua materi pelajaran penjasorkes harus mencapai minimal 75. Tapi pada kenyataan guru yang mengampu mata pelajaran penjasorkes menyebutkan masih banyak siswa yang belum mencapai ketuntasan minimal dalam pembelajaran khususnya lompat jauh gaya jongkok. Rata-rata nilai kelas menunjukkan angka $30 \%$ dari jumlah siswa, mendapat nilai dibawah 75 menjadi bukti kongkrit hasil belajar siswa masih belum mencapai KKM. Hal itu disebabkan siswa pada saat pembelajaran kurang memperhatikan penjelasan guru, pembelajaran kurang menarik, siswa asik ngobrol sendiri, terlalu banyak menunggu giliran sehingga siswa menjadi bosan dalam pembelajaran.

Dari penjelasan di atas dalam pelajaran Pendidikan Jasmani, Olahraga dan Kesehatan (Penjasorkes) ditemukan beberapa masalah yang kompleks pada saat proses pembelajaran lompat jauh. Dalam kegiatan pembelajaran tersebut siswa terlihat kurang berminat dalam mengikuti pelajaran dan kurang termotivasi untuk mau dan bisa melakukan teknik gerakan lompat jauh yang benar. Siswa cenderung asik ngobrol dan sibuk sendiri dengan kegiatan mereka. Menurut hasil pengamatan peneliti, rendahnya minat dan 
motivasi siswa untuk mata pelajaran Penjasorkes khususnya pada materi lompat jauh gaya jongkok di kelas VII B SMP Negeri 8 Surakarta tersebut disebabkan oleh beberapa faktor, diantarannya yaitu: (1) siswa terlihat kurang tertarik pada pelajaran Penjasorkes, (2) siswa cepat bosan pada saat mengikuti pelajaran Penjasorkes, (3) guru kurang kreatif menciptakan modifikasi alat-alat untuk pembelajaran Penjasorkes, (4) guru kesulitan dalam membangkitkan minat dan motivasi siswa.

Motivasi mendorong seseorang melakukan sesuatu untuk mencapai maksimal yang ingin dicapai. Motivasi adalah daya penggerak dalam diri seseorang untuk melakukan aktivitas tertentu, demi mencapai tujuan tertentu. Motivasi merupakan konsep yang menjelaskan alasan seseorang berperilaku. Seseorang yang motivasinya besar akan meningkatkan minat, perhatian, konsentrasi penuh, ketekunan tinggi, serta berorientasi pada prestasi tanpa mengenal perasaan bosan, jenuh, apalagi menyerah.

SMP Negeri 8 Surakarta adalah sebuah Sekolah Menengah Pertama yang terletak di daerah kota dan dilengkapi dengan sarana dan prasarana masih terbatas. Sehingga dalam pelaksanaan pembelajaran lompat jauh gaya jongkok dalam penjasorkes, kreativitas seorang guru sangat diperlukan, seorang guru harus bisa menciptakan suatu kondisi pembelajaran yang efektif dan menyenangkan meskipun dengan sarana dan prasarana yang terbatas. Sehingga diperlikan suatu model pembelajaran yang tepat.

Guru harus mendesain pembelajaran yang dapat meningkatkan minat dan motivasi siswa untuk mengikuti pembelajaran sehingga mencapai hasil belajar yang maksimal. Guru sangat berperan penting dalam upaya meningkatkan minat dan motivasi siswa dalam suatu proses pembelajaran, yaitu dengan cara 
memberi stimulus untuk menciptakan suatu kondisi pembelajaran yang menarik, antara lain dengan menggunakan metode pembelajaran dan alat pembelajaran dalam pelajaran penjasorkes salah satunya melalui pendekatan bermain, seperti contohnya (1) Permainan Loncat Katak, (2) Permainan Melompati Kardus, (3) Permaianan Melompati Ban, (4) Permainan bola gantung. Diharapkan dengan permainan tersebut tujuan pembelajaran lompat jauh gaya jongkok dapat tercapai seperti apa yang penulis inginkan. Berdasarkan permasalahan diatas, peneliti merasa tertarik untuk melakukan Penelitian Tindakan Kelas (PTK) pada siswa kelas VII B SMP Negeri 8 Surakarta dengan judul "Upaya Peningkatan Hasil Belajar Lompat Jauh Gaya Jongkok Melalui Pendekatan Bermain Pada Siswa Kelas VII B SMP Negeri 8 Surakarta Tahun Pelajaran 2017/2018."

\section{METODE PENELITIAN}

Metode penelitian yang digunakan adalah Penelitian PHEDHERAL Vol. 17 No. 2, Nov 2018
Tindakan Kelas. Subjek yang diteliti dalam Penelitian Tindakan Kelas (PTK) ini adalah semua siswa kelas VII B SMP Negeri 8 Surakarta tahun pelajaran 2017/2018, dengan jumlah 32 siswa.

Teknik pengumpulan data dalam Penelitian Tindakan Kelas ini terdiri atas: tes dan observasi. Tes dipergunakan untuk mendapatkan data tentang hasil belajar lompat jauh gaya jongkok yang dilakukan oleh siswa..

Observasi, digunakan sebagai teknik untuk mengumpulkan data tentang aktivitas siswa dan guru selama kegiatan pembelajaran

\section{HASIL DAN PEMBAHASAN}

Hasil belajar siswa dalam pembelajaran lompat jauh gaya jongkok setelah tindakan siklus I dilakukan menunjukkan hasil bahwa yang mencapai kriteria ketuntasan yaitu $46,88 \%$ atau 15 siswa. Sesuai dengan KKM sekolah untuk pendidikan Jasmani di SMP Negeri 8 Surakarta yaitu 75. Dalam hal ini sejumlah 15 siswa telah masuk dalam kriteria Tuntas sedangkan 17 
siswa Tidak Tuntas.

Berdasarkan

hasil

pelaksanaan pembelajaran pada

siklus I dan siklus II dapat disimpulkan bahwa telah terjadi peningkatan hasil belajar lompat jauh gaya jongkok pada siswa kelas VII B SMP Negeri 8 Surakarta tahun pelajaran 2017/2018. Dari hasil analisis yang diperoleh peningkatan yang signifikan terjadi pada data awal ke siklus I dan dari siklus I ke siklus II.

Kondisi awal siswa belum menunjukan hasil yang maksimal. Pada prasiklus hasil belajar lompat jauh gaya jongkok yang sudah mencapai kriteria ketuntasan 10 siswa atau $31,25 \%$ dan yang belum mencapai kriteria ketuntasan 22 siswa atau $68,75 \%$, jumlah siswa yang Tuntas adalah 10 peserta siswa dan 22 siswa Belum Tuntas. Hal tersebut disebabkan media atau metode pembelajaran yang digunakan untuk materi lompat jauh gaya jongkok belum tepat, sehingga siswa cepat merasa bosan dan tidak tertarik terhadap pembelajaran dan berakibat terhadap hasil belajar siswa yang kurang maksimal.

$$
\text { Pada siklus I hasil belajar }
$$
lompat jauh gaya jongkok sudah menunjukan peningkatan, yang mencapai kriteria ketuntasan 15 siswa atau 46,88\% dan yang belum mencapai kriteria ketuntasan 17 siswa atau 53,12 \%, jumlah siswa yang Tuntas adalah 15 siswa dan 17 siswa Belum Tuntas. Minat siswa dalam mengikuti pembelajaran meningkat, siswa merasa senang dengan pembelajaran yang diberikan sehingga muncul antusiasme siswa dalam mengikuti pembelajaran dan membuat hasil belajar mereka meningkat. Siklus II merupakan tindak lanjut dari hasil analisis dan refleksi yang dilakukan oleh peneliti dan kolabolator dalam siklus I. Keberhasilan yang ada pada pelaksanaan pembelajaran siklus I akan dipertahankan dan ditingkatkan pada pelaksanaan pembelajaran siklus II. Dengan cara yaitu menambah level kompleksitas menggunakan metode pendekatan bermaian pada siklus I. Hasil belajar lompat jauh gaya jongkok pada pembelajaran siklus II yaitu yang 
sudah mencapai kriteria 26 siswa atau $81,25 \%$ dan yang belum mencapai kriteria ketuntasan 6 siswa atau $18,75 \%$, jumlah siswa yang Tuntas adalah 26 siswa dan 6 siswa Belum Tuntas.

\section{SIMPULAN DAN \\ SARAN}

\section{Simpulan}

Penelitian Tindakan Kelas pada siswa kelas VII B SMP Negeri 8 Surakarta tahun pelajaran 2017/2018 dilaksanakan dalam dua Siklus. Setiap siklus terdiri atas empat tahapan, yaitu:

Perencanaan, (2) Pelaksanaan

Tindakan, (3) Observasi dan Interpretasi dan (4) Analisis dan Refleksi. Pelaksanaan setiap siklus terdiri dari 2 kali pertemuan. Berdasarkan analisis data yang telah dilakukan, diperoleh hasil sebagai berikut: Hasil analisis data menunjukkan adanya peningkatkan hasil belajar lompat jauh gaya jongkok dari Pra Tindakan ke Siklus I dan dari Siklus I ke Siklus II. Hal ini dapat dilihat dari pencapaian hasil belajar pada Pra Tindakan hasil belajar lompat jauh gaya jongkok yang sudah mencapai kriteria ketuntasan 10 siswa atau 31,25\% dan yang belum mencapai kriteria ketuntasan 22 siswa atau 68,75\%, jumlah siswa yang Tuntas adalah 10 siswa. Pada Siklus I hasil belajar lompat jauh gaya jongkok yang mencapai kriteria ketuntasan 15 siswa atau 46,88\% dan yang belum mencapai kriteria 17 siswa atau $53,12 \%$, jumlah siswa yang Tuntas adalah 15 siswa. Sedangkan pada Siklus II hasil belajar lompat jauh gaya jongkok yang sudah mencapai kriteria ketuntasan 26 siswa atau $81,25 \%$ dan yang belum mencapai kriteria ketuntasan 6 siswa atau $18,75 \%$, jumlah siswa yang Tuntas adalah 26 siswa.

Berdasarkan hasil analisis diatas maka dapat disimpulkan bahwa menggunakan metode pendekatan bermain dapat meningkatkan hasil belajar lompat jauh gaya jongkok siswa kelas VII B SMP Negeri 8 Surakarta tahun pelajaran 2017/2018

\section{Saran}

Sesuai dengan simpulan dan implikasi hasil penelitian, serta dalam rangka ikut menyumbangkan 
pemikiran bagi guru dalam meningkatkan penguasaan belajar, khususnya bidang studi penjasorkes, maka dapat disampaikan saran-saran sebagai berikut:

1. Bagi Guru Kelas VII B SMP Negeri 8 Surakarta

a Guru hendaknya terus berusaha meningkatkan kemampuannya dalam mengembangkan dan menyampaikan materi kepada siswa, meningkatkan diri dalam hal pengelolaan kelas, sehingga kualitas pembelajaran yang dilakukannya dapat terus meningkat seiring dengan peningkatan kemampuan yang dimilikinya. Selain itu, guru hendaknya mau memperbaiki kualitas mengajarnya.

b. Dalam proses pembelajaran harusnya guru memperhatikan kondisi siswa dan menggunakan strategi mengajar yang bervariasi. Dengan demikian motivasi dan keaktifan siswa akan meningkat pada mata pelajaran pendidikan jasmani.

c. Guru hendaknya lebih kreatif dalam membuat dan mengembangkan modifikasi media pembelajaran sehingga akan menciptakan pembelajaran yang aktif dan menyenangkan.

d. Kepada guru yang belum menerapkan menggunakan metode pendekatan bermain hendaknya mencoba teknik tersebut untuk meningkatkan hasil belajar siswanya.

2. Bagi Siswa Kelas VII B

SMP Negeri 8

Surakarta

a. Siswa harus siap untuk mengikuti

pemb elajaran dengan strategi pembelajaran apapun yang diberikan guru dan selalu bersedia dengankesadaran sendiri untuk mengikuti petunjuk dan arahan yang diberikan guru. 
b. Siswa perlu lebih meningkatkan berbagi aktivitas dan mengembangkan berbagi metode belajar sekaligus sebagai sarana memperluas pengetahuan dan wawasannya dan belajar secara mandiri, mengerjakan tugas-tugas dari guru untuk berlatih untuk mempraktikkan teknik serta gerak dasar dan gerakan yang ada didalam suatu cabang olahraga yang diajarkan.

3. Bagi sekolah
a. Sekolah
hendaknya membuat kebijakan kepada

$$
\begin{aligned}
& \text { guru untuk melakukan } \\
& \text { penelitian tindakan kelas } \\
& \text { dalam rangka meningkatkan } \\
& \text { kualitas proses pembelajaran } \\
& \text { dikelas menggunakan } \\
& \text { metode pendekatan bermain } \\
& \text { agar pembelajaran lebih } \\
& \text { inovatif sehingga tujuan } \\
& \text { pembelajaran dapat tercapai. }
\end{aligned}
$$

4. Bagi peneliti

a. Perlu diadakanya penelitian sejenis dengan cakupan materi yang lebih luas sehingga dapat diketahui sejauh mana menggunakan metode pendekatan bermain akan meningkatkan hasil belajar lompat jauh gaya jongkok 


\section{DAFTAR PUSTAKA}

Agus Kristiyanto. (2010). Penelitian Tindakan Kelas (PTK) dalam Pendidikan Jasmani dan Kepelatihan Olahraga. Surakarta: UNS Press.

Ahmad Susanto. (2015). Teori Belajar dan Pembelajaran di Sekolah Dasar. Jakarta: Kencana.

Aunurrahman. (2016). Belajar dan Pembelajaran. Bandung: Alfabeta.

Dimyati dan Mudjiono. (2010). Belajar dan Pembelajaran. Jakarta: PT. Rineka Cipta.

Dikdik Zafar Sidik. (2017). Mengajar dan Melatih Atletik. Bandung. PT . Remaja Rosdakarya.

Furqon Hidayatullah. (2008). Mendidik Anak dengan Bermain. Surakarta: UNS Press.

Gerry A. Carr. (1997). Atletik Untuk Sekolah. Jakarta: PT. Raja Grafindo Persada.

Idey Setiasih. (2010). Lompat Jauh. Sukoharjo: Hamudha Prima Media.

Samsudin. (2008). Pemanfaatan Lingkungandalam Pembelajaran Penjas. Jakarta: Universitas Terbuka.

Slameto. (2013). Belajar dan Faktor-FaktorYang Mempengaruhinya. Jakarta. Rineka Cipta.

Suyono dan Hariyanto. (2014). Belajar dan Pembelajaran. Bandung: PT. Remaja Rosdakarya.

Wina Sanjaya. (2013). Strategi Pembelajaran.Jakarta: Kencana.

Yoyo Bahagia dan Adang Suherman. (2000).Prinsip-Prinsip Pengembangan dan Modifikasi Cabang Olahraga. Jakarta: 